$12-8-2003$

\title{
C-Ring Strength of Advanced Monolithic Ceramics
}

\author{
A. A. Wereszczak \\ U.S. Army Research Laboratory \\ R. J. Caspe \\ U.S. Army Research Laboratory \\ J. J. Swab \\ U.S. Army Research Laboratory \\ S. F. Duffy \\ Connecticut Reserve Technologies \\ E. H. Baker \\ Connecticut Reserve Technologies
}

Follow this and additional works at: https://engagedscholarship.csuohio.edu/encee_facpub

Part of the Civil and Environmental Engineering Commons

How does access to this work benefit you? Let us know!

\section{Recommended Citation}

Wereszczak, A. A.; Caspe, R. J.; Swab, J. J.; Duffy, S. F.; and Baker, E. H., "C-Ring Strength of Advanced Monolithic Ceramics" (2003). Civil and Environmental Engineering Faculty Publications. 378.

https://engagedscholarship.csuohio.edu/encee_facpub/378

This Conference Paper is brought to you for free and open access by the Civil and Environmental Engineering at EngagedScholarship@CSU. It has been accepted for inclusion in Civil and Environmental Engineering Faculty Publications by an authorized administrator of EngagedScholarship@CSU. For more information, please contact library.es@csuohio.edu. 


\title{
C-RING STRENGTH OF ADVANCED MONOLITHIC CERAMICS
}

\author{
A. A. Wereszczak, ${ }^{1}$ R. J. Caspe, ${ }^{2}$ and J. J. Swab \\ Metals and Ceramics Research Branch \\ U. S. Army Research Laboratory \\ Aberdeen Proving Ground, MD 21005 \\ S. F. Duffy and E. H. Baker \\ Connecticut Reserve Technologies \\ Cleveland, $\mathrm{OH} 44114$
}

\begin{abstract}
Alumina, silicon carbide, silicon nitride, and zirconia are common candidate ceramics for load-bearing tubular components. To help facilitate design and reliability modeling with each ceramic, Weibull strength distributions were determined with each material using a diametrally compressed c-ring specimen in accordance with ASTM C1323. The investigated silicon nitride and zirconia were found to exhibit higher uncensored characteristic strengths than the alumina and silicon carbide. The occurrence of chamfer-located fracture initiation was problematic, and hindered the ability to generate valid design data in some of these ceramics. Fractography and stress modeling results suggest that some aspects of ASTM C1323 should be revised to further minimize the frequency of chamfer-located failure initiation in c-ring test specimens.
\end{abstract}

\section{INTRODUCTION}

Confident strength-size-scaling and probabilistic design of internally pressurized tubular ceramic components can result when censored Weibull strength distribution data are available for input. Therefore, a goal of a structural ceramic component designer is to have access to censored strength data that are the result of the exploitation of all possible strength-limiting flaws that may be active in the service life of the component.

1 Now with the Structural Ceramic Group, Metals and Ceramics Division, Oak Ridge National Laboratory, Oak Ridge, TN 37831-6068.

2 Undergraduate student, Department of Ceramic and Materials Engineering, Rutgers University, Piscataway, NJ 08854. 


\section{Report Documentation Page}

Form Approved

OMB No. 0704-0188

Public reporting burden for the collection of information is estimated to average 1 hour per response, including the time for reviewing instructions, searching existing data sources, gathering and maintaining the data needed, and completing and reviewing the collection of information. Send comments regarding this burden estimate or any other aspect of this collection of information,

including suggestions for reducing this burden, to Washington Headquarters Services, Directorate for Information Operations and Reports, 1215 Jefferson Davis Highway, Suite 1204, Arlington

VA 22202-4302. Respondents should be aware that notwithstanding any other provision of law, no person shall be subject to a penalty for failing to comply with a collection of information if it

does not display a currently valid OMB control number.

\begin{tabular}{|c|c|c|}
\hline $\begin{array}{l}\text { 1. REPORT DATE } \\
\mathbf{2 0 0 3}\end{array}$ & $\begin{array}{l}\text { 2. REPORT TYPE } \\
\text { N/A }\end{array}$ & $\begin{array}{l}\text { 3. DATES COVERED } \\
\text { - }\end{array}$ \\
\hline \multirow{3}{*}{\multicolumn{2}{|c|}{ C-Ring Strength of Advanced Monolithic Ceramics }} & 5a. CONTRACT NUMBER \\
\hline & & 5b. GRANT NUMBER \\
\hline & & 5c. PROGRAM ELEMENT NUMBER \\
\hline \multirow{3}{*}{\multicolumn{2}{|c|}{ 6. AUTHOR(S) }} & 5d. PROJECT NUMBER \\
\hline & & 5e. TASK NUMBER \\
\hline & & 5f. WORK UNIT NUMBER \\
\hline \multicolumn{2}{|c|}{$\begin{array}{l}\text { 7. PERFORMING ORGANIZATION NAME(S) AND ADDRESS(ES) } \\
\text { Oak Ridge National Laboratory Bethel Valley Rd PO Box } 2008 \text { Oak } \\
\text { Ridge, TN 37831-6063 }\end{array}$} & $\begin{array}{l}\text { 8. PERFORMING ORGANIZATION } \\
\text { REPORT NUMBER }\end{array}$ \\
\hline \multirow{2}{*}{\multicolumn{2}{|c|}{ 9. SPONSORING/MONITORING AGENCY NAME(S) AND ADDRESS(ES) }} & 10. SPONSOR/MONITOR'S ACRONYM(S) \\
\hline & & $\begin{array}{l}\text { 11. SPONSOR/MONITOR'S REPORT } \\
\text { NUMBER(S) }\end{array}$ \\
\hline
\end{tabular}

12. DISTRIBUTION/AVAILABILITY STATEMENT

Approved for public release, distribution unlimited

13. SUPPLEMENTARY NOTES

14. ABSTRACT

15. SUBJECT TERMS

16. SECURITY CLASSIFICATION OF:

a. REPORT

unclassified b. ABSTRACT unclassified c. THIS PAGE unclassified
17. LIMITATION OF ABSTRACT

UU
18. NUMBER

OF PAGES

8 19a. NAME OF

RESPONSIBLE PERSON 
Hoop stresses result from internal pressurization of tubes, so a goal of the present study was to determine strength distributions that were limited by flaws located on the outside diameter for four different ceramics. This was accomplished by diametrally compressing alumina $\left(\mathrm{Al}_{2} \mathrm{O}_{3}\right)$, silicon carbide $(\mathrm{SiC})$, silicon nitride $\left(\mathrm{Si}_{3} \mathrm{~N}_{4}\right)$, and zirconia $\left(\mathrm{ZrO}_{2}\right)$ c-ring specimens to failure. The results from these tests, as well as those from analyses performed to supplement the strength testing, are described.

\section{EXPERIMENTAL PROCEDURES}

C-ring specimens were machined from $33 \mathrm{~mm}$ O.D. x $24 \mathrm{~mm}$ I.D. x $100 \mathrm{~mm}$ long tubes of four monolithic ceramics: $99.5 \% \mathrm{Al}_{2} \mathrm{O}_{3}$ (AD995, CoorsTek, Golden, $\mathrm{CO}$ ); a pressureless sintered SiC (Enhanced Hexoloy SA, Saint-Gobain Advanced Ceramics Corp., Niagara Falls, NY); a reaction-bonded and sintered $\mathrm{Si}_{3} \mathrm{~N}_{4}$ (Ceralloy 147-31N, Ceradyne, Inc., Costa Mesa, CA); and a ceria-doped TZP Z $\mathrm{ZO}_{2}$ (Ce-TZP, CoorsTek, Golden, CO). Circumferential machining and a minimum surface finish of $0.8 \mu \mathrm{m}$ on the outer diameter of all tubes were requested of each vendor. C-ring specimens having a $8 \mathrm{~mm}$ width, longitudinal $45^{\circ}$ chamfers to a distance of $0.15 \mathrm{~mm}$, and a slot height of $5.7 \mathrm{~mm}$ were prepared by a commercial machine company (Chand Kare Technical Ceramics, Worcester, MA) per ASTM C1323 [1].

C-ring specimens were strength tested using an electromechanical test frame (Instron 1127, Canton, MA). A displacement rate of $0.5 \mathrm{~mm} / \mathrm{min}$ was used to compressively and diametrally load the c-ring specimens to failure. Paper shims were used between the upper and lower contact locations to minimize the likelihood of contact-induced fracture. The geometry and failure loads were used to calculate the hoop or OD tangential failure stress $\left(\square_{\square \max }\right)$ for each specimen according to the strength of materials solution in ASTM 1323 [1]:

$$
\square_{\square \max }=\frac{P R}{b t r_{o}} \underset{r_{o} \square r_{a} \square R}{=} \frac{5}{=}
$$

where $\mathrm{P}$ is the failure load, $\mathrm{r}_{\mathrm{o}}$ is the outer c-ring radius, $\mathrm{r}_{\mathrm{i}}$ is the inner c-ring radius, $\mathrm{r}_{\mathrm{a}}$ is the average of $r_{o}$ and $r_{i}$, $b$ is width, $t$ is thickness or $r_{o}-r_{i}$, and $R=\left(r_{o}-r_{i}\right) / \ln \left(r_{o} / r_{i}\right)$.

Additional analyses were performed to assist in the interpretation of the strength results. Failure locations for all specimens were identified using optical fractography according to ASTM C1322 [2]. Also, the effective area and effective volume of the investigated c-ring were determined using finite element analysis (FEA) [3] and CARES [4], and compared with those stemming from Eq. 1 [5].

\section{RESULTS \& DISCUSSION}

The location-censored Weibull strength-distributions for the $\mathrm{AD} 995 \mathrm{Al}_{2} \mathrm{O}_{3}$, Enhanced Hexoloy SA SiC, Ceralloy 147-31N Si ${ }_{3} \mathrm{~N}_{4}$, and Ce-TZP $\mathrm{ZrO}_{2}$ are shown in Figs. 1-4. Uncensored two-parameter (characteristic strength and Weibull modulus) distribution values are also indicated on each graph. Although they show that the $\mathrm{Si}_{3} \mathrm{~N}_{4}$ and $\mathrm{ZrO}_{2}$ were qualitatively the strongest of the four sets, their

usefulness is quite limited (if not outright misleading) for design purposes because they represent the combination of two or more strength limiting flaw types. 
The recommended chamfer geometry in ASTM C1323 did not satisfactorily work with all the investigated monolithic ceramics. The chamfering procedure worked satisfactorily for the $\mathrm{AD} 995 \mathrm{Al}_{2} \mathrm{O}_{3}$ and $\mathrm{Ce}-\mathrm{TZP} \mathrm{ZrO}_{2}$ because there was a relative equal blend of both chamfer-located failures and surface-located failures. This is a useful circumstance for design and guidance of any future c-ring machining of tubes made from these ceramics. However, chamfer-located failures dominated the fracture of the Hexoloy SA SiC and Ceralloy 147-31 $\mathrm{N} \mathrm{Si}_{3} \mathrm{~N}_{4}$ c-rings as they were undersized $(\sim 0.08-0.13 \mathrm{~mm}$ versus $0.15 \mathrm{~mm}$ ASTM C1323 recommendation). Consequently, the strength potential of both these ceramics was not exploited by these c-ring tests and sufficient design data was not generated for either ceramic. If future c-ring tests were to be performed with these ceramics, then the chamfer machining (e.g., alternative chamfer geometry, etc.) procedure would need to be changed so as to promote surface-located failure initiation.

The higher frequency of chamfer-located failures may have been a consequence of unanticipated higher stresses existing there [5]. The FEA-predicted higher stresses (compared to the idealized strength of materials solution of Eq. 1) near the chamfer/edges shown in Fig. 5 is consistent with the general observation that there was a relatively high fraction of chamfer failures than surface failures in all the materials with the exception of the $\mathrm{AD} 995 \mathrm{Al}_{2} \mathrm{O}_{3}$. Additionally, chamfer-located failures in Enhanced Hexoloy SA SiC and Ceralloy 147-31N $\mathrm{Si}_{3} \mathrm{~N}_{4}$ had their mirror plane perfectly aligned with machining grooves present on one side of the c-ring (not observed with the AD995 $\mathrm{Al}_{2} \mathrm{O}_{3}$ and Ce-TZP $\mathrm{ZrO}_{2}$ ). These observations suggest that finer-grit and less aggressive machining should be prescribed for the machining of the sides of the c-rings for Enhanced Hexoloy SA SiC and Ceralloy 147-31N Si $\mathrm{N}_{4}$.

The determination of effective area and effective volume was revisited on account of the stress differences illustrated in Fig. 5, and their idealized [6] representations were found to be non-conservative for structural design, Figs. 6-7. For example, the failure stress of an arbitrary component $\left(\mathrm{S}_{\mathrm{B}}\right)$ that is limited by surface strengthlimiting flaws is represented by

$$
S_{B}=\stackrel{\square k_{A A} A_{A}}{\sum_{A B} A_{B}} \square^{/ m_{A}} S_{A},
$$

where $\mathrm{k}_{\mathrm{AA}} \mathrm{A}_{\mathrm{A}}$ and $\mathrm{k}_{\mathrm{AB}} \mathrm{A}_{\mathrm{B}}$ are effective areas for a test coupon (e.g., c-ring) and component, respectively, $\mathrm{m}_{\mathrm{A}}$ is the censored Weibull modulus, and $\mathrm{S}_{\mathrm{A}}$ is the characteristic strength of the test coupon. If $\mathrm{m}_{\mathrm{A}}$ is taken to be 20 for the investigated c-ring geometry in the present study and $\mathrm{k}_{\mathrm{AB}} \mathrm{A}_{\mathrm{B}}$ is unity, then $\mathrm{S}_{\mathrm{B}}$ would be $\sim 21 \%$ and $24 \%$ more than $S_{\mathrm{A}}$ for the CARES and closed form solutions, respectively. The close form solution is non-conservative. The CARES solution in this example is more accurate and representative because the closed form solution does not represent the actual stress state at the c-ring ends while the FEA did.

\section{SUMMARY}

The uncensored characteristic strengths of Ceralloy 147-31N $\mathrm{Si}_{3} \mathrm{~N}_{4}$ and Ce-TZP $\mathrm{ZrO}_{2}$ were higher than $\mathrm{AD} 995 \mathrm{Al}_{2} \mathrm{O}_{3}$ and Enhanced Hexoloy SA SiC. Nonadherence (undersizing) of chamfer machining guidelines in ASTM C1323 appears to have promoted higher frequencies of failure initiation at the chamfer/edge. A 
chamfer size of $0.15 \mathrm{~mm}$ may not be sufficient to minimize the frequency of failure initiation at the chamfer/edge in stronger ceramics. The relatively rough surface finish on the AD995 and Ce-TZP appeared to be associated with higher frequencies of surface failures. That is useful for design; however, potential strength of the materials probably was not sampled. FEA showed higher $\square_{T}$ existed at the chamfer/edges than that predicted by the strength of materials solution, and that may have contributed to the high frequency of failures located there. The non-constant $\square_{\mathrm{T}}$ in the loaded c-ring geometry manifested itself in lower effective areas and volumes (for the same Weibull modulus) than those predicted from the (constant $\square_{\mathrm{T}}$ ) strength of materials solution.

\section{ACKNOWLEDGEMENTS}

The authors wish to thank J. Adams, R. Carter, J. G. Hemrick and H. -T. Lin for their review of the manuscript and helpful comments. R. J. Caspe was supported by the USARL Materials Center of Excellence at Rutgers University, High Fidelity Design and Processing of Advanced Armor Ceramics.

\section{REFERENCES}

[1] ASTM C1323, "Standard Test Method for Ultimate Strength of Advanced Ceramics with Diametrally Compressed C-Ring Specimens at Ambient Temperature," Annual Book of ASTM Standards, Vol. 15.01, American Society for Testing and Materials, West Conshohocken, PA, 2001.

[2] ASTM C1322, "Standard Practice for Fractography and Characterization of Fracture Origins in Advanced Ceramics," Annual Book of ASTM Standards, Vol. 15.01, American Society for Testing and Materials, West Conshohocken, PA, 2001.

[3] ANSYS, Release 5.7, Canonsburg, PA.

[4] N. N. Nemeth, J. M. Manderscheid, J. P. Gyekenyesi, "Ceramic Analysis and Reliability Evaluation of Structures (CARES)," Users and Programmers Manual, Report TP-2916, National Aeronautics and Space Administration, 1990.

[5] S. F. Duffy and E. H. Baker, "Evaluation of Effective Volume \& Effective Area for C-Ring Test Specimen," Contract DAAD17-02-P-0503, USARL Technical Report, in press, 2003.

[6] O. M. Jadaan, D. L. Shelleman, J. C. Conway, Jr., J. J. Mecholsky, Jr., and R. E. Tressler, "Prediction of the Strength of Ceramic Tubular Components: Part I - Analysis," ASTM Journal of Testing and Evaluation, 19 181-91 (1991). 


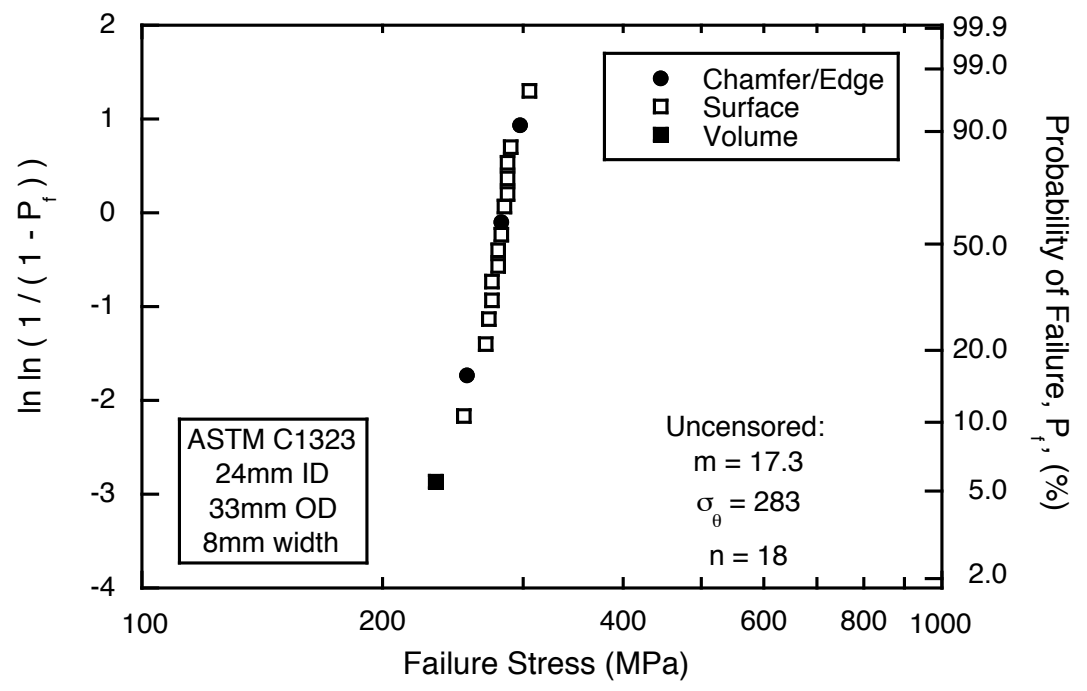

Fig. 1. Location-censored Weibull strength distribution for $\mathrm{AD} 995 \mathrm{Al}_{2} \mathrm{O}_{3}$ C-rings. Failure stress calculated using Eq. 1.

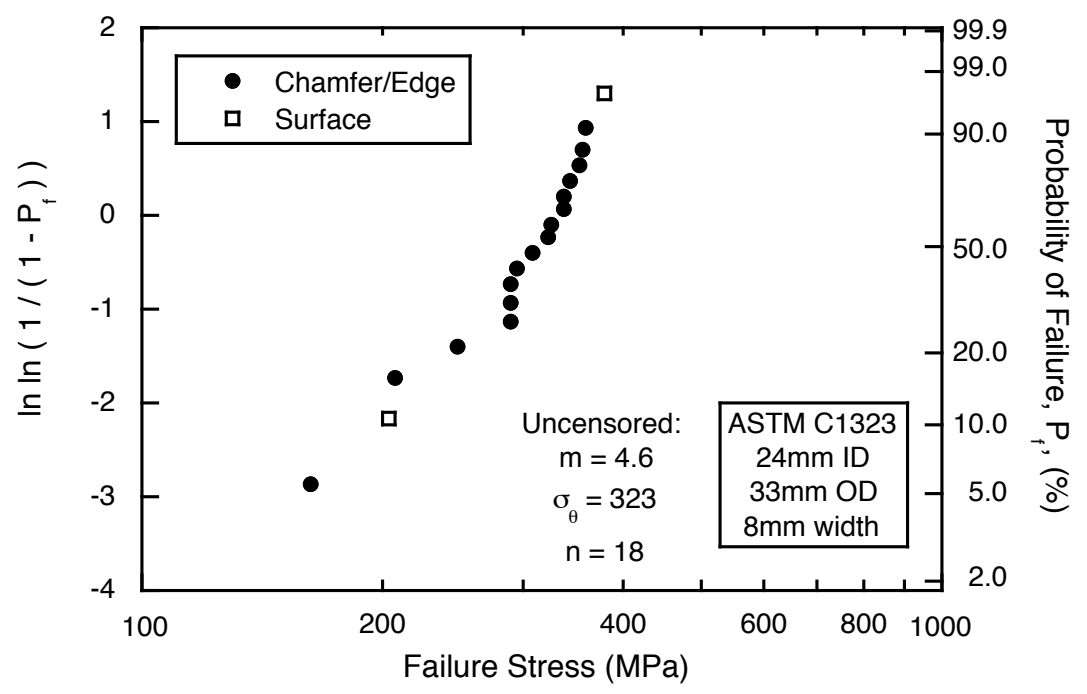

Fig.2. Location-censored Weibull strength distribution for Enhanced Hexoloy SA SiC C-rings. Failure stress calculated using Eq. 1. 


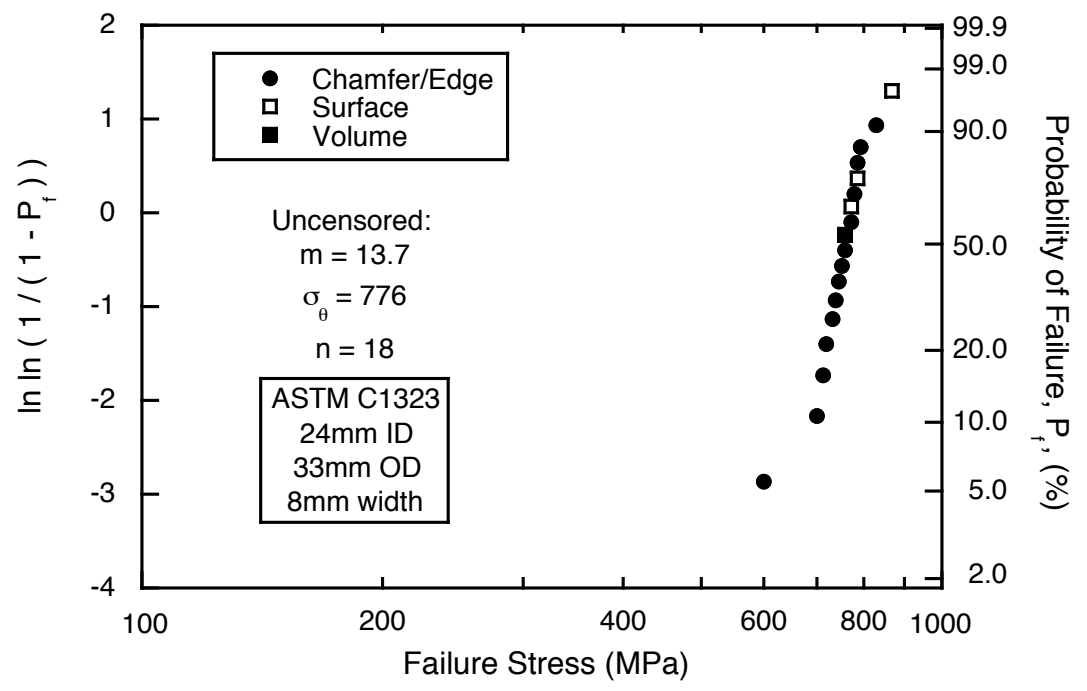

Fig. 3. Location-censored Weibull strength distribution for Ceralloy 147-31N $\mathrm{Si}_{3} \mathrm{~N}_{4}$ C-rings. Failure stress calculated using Eq. 1.

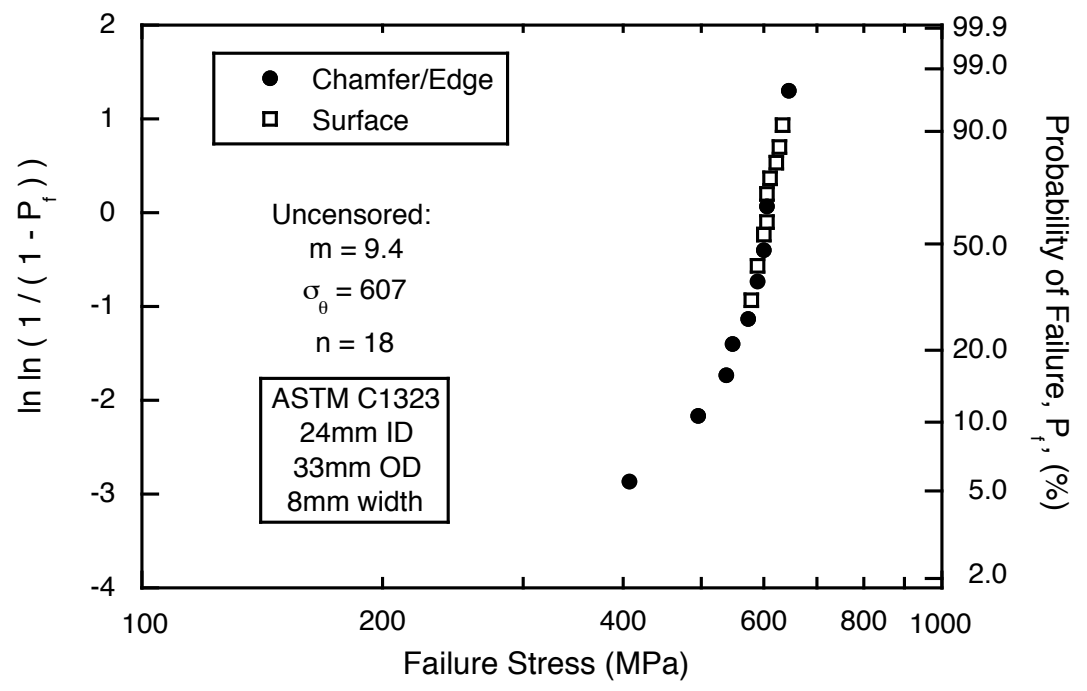

Fig. 4. Location-censored Weibull strength distribution for Ce-TZP $\mathrm{ZrO}_{2}$ C-rings. Failure stress calculated using Eq. 1. 


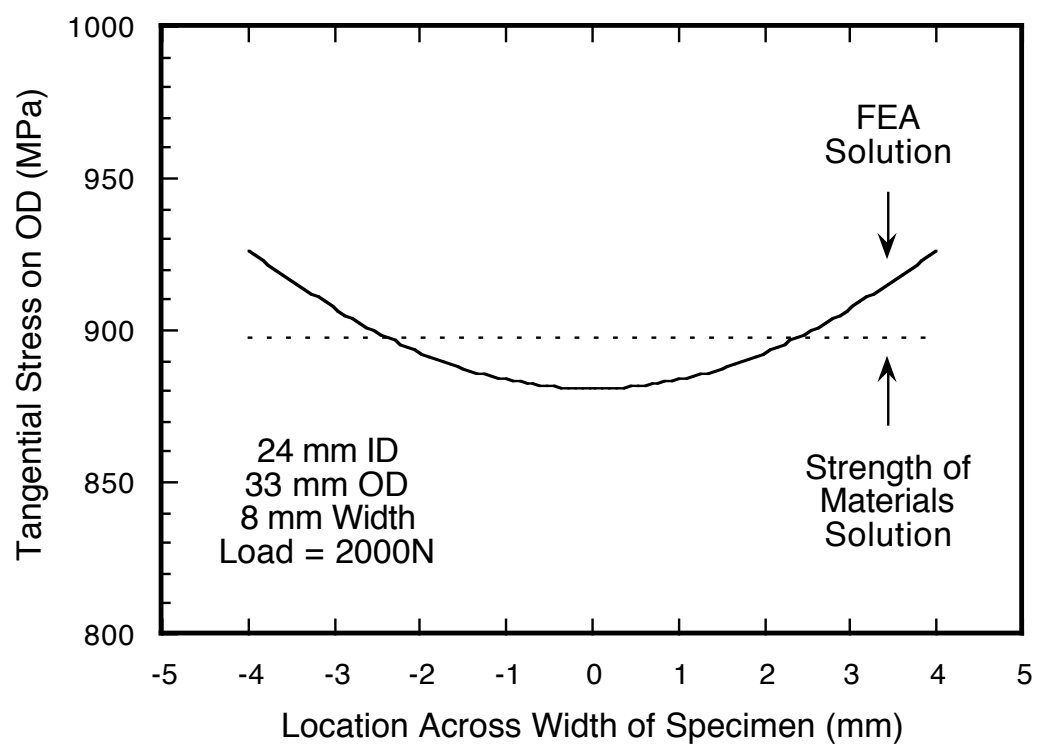

Fig. 5. The FEA solution exhibited a nonuniform stress level across the width of the $8 \mathrm{~mm}$ c-ring (5\% increase from the center to the edges). Additionally, the edge stress was $3 \%$ higher than that of the closed form solution.

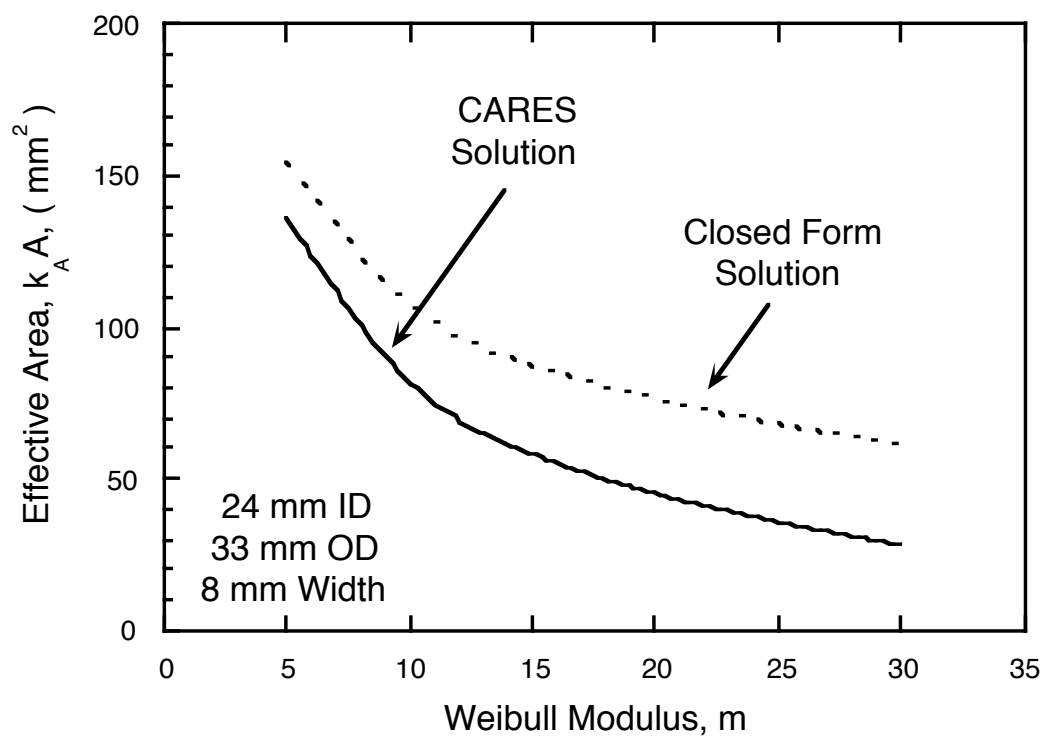

Fig. 6. The effective area is greater for the closed form solution (Eq. 1) than the CARES solution for any Weibull modulus. 


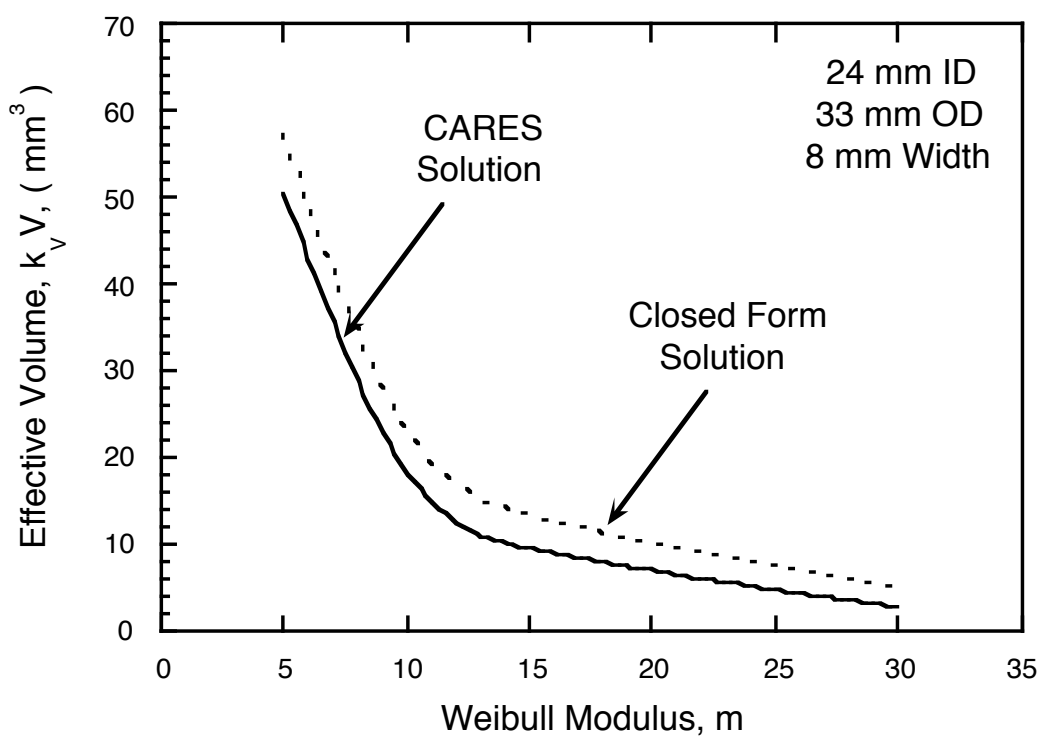

Fig. 7. The effective volume is greater for the closed form solution (Eq. 1) than the CARES solution for any Weibull modulus. 